\title{
Genetic Differentiation of Carassius auratus and C. cuvieri by the Cytochrome C Oxidase I Gene Analysis
}

\author{
Jung-Ha Kang*, Eun-Soo Noh, Jae-Hyun Lim, Hyeung-Kyun Han, Bong-Seok Kim, and Sang-Ku Lim
}

Biotechnology Research Division, NFRDI, Busan 619-705, Republic of Korea

\begin{abstract}
It is estimated that 27 bony fish species have been introduced into Korean freshwaters for aquaculture and the enhancement of fishery resources. Among them, Carassius cuvieri has completely adapted and is widely distributed throughout Korean freshwater ecosystems. In this study we investigated the genetic relationship between C. cuvieri and the closely related native crucian carp species Carassius auratus. Nucleotide sequence variation within the mtDNA cytochrome $c$ oxidase I (COI) gene was used to study the genetic divergence and phylogenetic relationships among the species and to identify their taxonomic status in the family Cyprinidae. We compared partial COI gene sequences ( 630 base pairs) from three populations of $C$. auratus and three populations of $C$. cuvieri. A total of 46 variable sites were identified from 163 individuals, yielding 23 haplotypes. The two species showed very close genetic relationship with $95 \%$ sequence identity in the $\mathrm{COI}$ gene, the frequency and distribution of haplotypes showed clear separation, suggesting divergent evolution of these two species. Therefore, despite the morphological similarity and phylogenetic closeness, the populations of these two species should be regarded as separate management units in the ongoing recovery program.
\end{abstract}

Keywords: Carp; CO1; Genetic differentiation; Hybrid; Triploid

\section{Introduction}

Although the introduction of exotic species to aquatic ecosystems can result in many problems, including habitat alternation, the introduction of diseases and parasites, and hybridization with native species, 27 bony fish species have been introduced into Korean freshwaters for aquaculture and the enhancement of fishery resources. Among them, the Japanese crucian carp Carassius cuvieri, also known as the white crucian carp, was introduced from Japan in 1972. C. cuvieri has since completely adapted and is now widely distributed throughout the domestic freshwater ecosystems of Korea [1]

The classification of species in the genus Carassius is highly controversial due to the morphological similarity of the different species; as a result, crucian carp are classified into either two or five species [2,3]. The species and their distributions in the five species system are as follows: Carassius throughout most of Europe and western Asia; Carassius langsdorfii and C. cuvieri in Japan; Carassius auratus in China; and Carassius gibelio in Europe, Siberia, and East Asia [2,4-6]. C. carassius is the only species that can be identified easily by its morphological characteristics [7]. The two-species system includes C. carassius, and many subspecies of $C$. auratus in different habitats and in geographical isolation: C. auratus auratus in China; C. auratus gibelio in Europe and China; and another four subspecies, C. auratus cuvieri, C. auratus grandoculis, C. auratus buergeri, and C. auratus langsdorfii in Japan [8,9]. In addition, many geographic populations have been reported in China [10-12].

In addition to the morphological similarity and the presence of subspecies, the identification of Carassius species is further complicated by the occurrence of specimens with different ploidy levels. It was long believed that $C$. gibelio and C. langsdorfii were triploid, in contrast to the other species, which were believed to be diploid, and ploidy level was used as an important characteristic in species identification [13]. However, diploidy has been observed within C. gibelio and C. langsdorfii, and triploidy has recently been observed in C. auratus $[3,14,15]$. Also, the existence of hybrids between various Carassius species, such as hybrids between C. carassius and C. auratus, further complicates species identification [16].
In order to overcome the limitations in the morphological identification of Carassius species, molecular genetic markers, such as random amplified polymorphic DNA [17], microsatellite DNA [18,19], and partial sequences of mitochondrial DNA [20-22] have been used for the identification of species, ploidy, clonal lineages, and phylogenetic relationships. Because of its small size, maternal inheritance, and rapid rate of evolution, mtDNA is often used as a genetic marker in phylogenetic and evolutionary studies in vertebrates, including fish [23]. Within mtDNA, the control region (D-loop), cytochrome b gene, and cytochrome c oxidase subunit I (COI) gene are most frequently used in animal molecular taxonomy and bioidentification studies [24]

Japanese crucian carps into two species, C. cuvieri and C. auratus were classified [2], and others have confirmed this classification using molecular markers $[19,20,21]$. Similarly, C. auratus, the species endemic to Korea, and C. cuvieri, the exotic species, are two distinct species that live in Korean freshwaters. However, there has been no study of the genetic diversity and phylogenetic relationships among populations of the latter two species. Therefore, we investigated the patterns of sequence variation in the mtDNA COI gene region in the crucian carp population to describe the genetic diversity and genetic structure of the C. cuvieri and C. auratus populations.

\section{Materials and Methods}

\section{Sampling and DNA extraction}

C. auratus and C. cuvieri samples were collected from the

*Corresponding author: Jung-Ha Kang, Biotechnology Research Division, NFRDI, Busan 619-705, Republic of Korea, Tel: 82-51-720-2462; E-mail: genetics@korea.kr

Received March 18, 2014; Accepted April 21, 2014; Published April 03, 2014

Citation: Kang JH, Noh ES, Lim JH, Han HK, Kim BS, et al. (2014) Genetic Differentiation of Carassius auratus and $C$. cuvieri by the Cytochrome C Oxidase Gene Analysis. J Aquac Res Development 5: 231 doi:10.4172/2155-9546.1000231

Copyright: $\odot 2014 \mathrm{Kang} \mathrm{JH}$, et al. This is an open-access article distributed under the terms of the Creative Commons Attribution License, which permits unrestricted use, distribution, and reproduction in any medium, provided the original author and source are credited. 
Yeongsan, Geum, and Nakdong rivers. Fishes were collected using nets and identified by morphology by a specialist. Among the fishes collected from the Yeongsan, Geum, and Nakdong rivers, the $C$. auratus individuals numbered 45,20 , and 29 , and the C. cuvieri individuals numbered 28,16 , and 23 , respectively. Fin tissues were preserved in $100 \%$ ethanol at the sampling site, and then transported to the laboratory for DNA extraction. Tissue $(20 \mathrm{mg})$ was lysed in lysis buffer (MFX-2000, Toyobo, Osaka, Japan) containing $20 \mathrm{mg} / \mathrm{ml}$ of proteinase $\mathrm{K}$, and then total DNA was extracted using a Mag Extractor MFX-6100 automated DNA extraction system (Toyobo).

\section{mtDNA COI gene sequence amplification and analysis}

The HCO2198 and LCO1490 primers were used for the amplification of a partial sequence of the COI gene [25]. PCR amplification was performed in $30-\mu \mathrm{l}$ reaction mixtures containing $3 \mu$ lemplate DNA, $1 \mu \mathrm{l}(10 \mathrm{pM} / \mu 1)$ each of forward and reverse primers, $3 \mu \mathrm{l}$ of $10 \times \mathrm{Taq}$ PCR buffer, $2.4 \mu \mathrm{l}$ of dNTP mixture $(2.5 \mathrm{~mm}$ each), and $0.6 \mu \mathrm{l}$ of Taq DNA polymerase $(5 \mathrm{U} / \mu \mathrm{l})$ using a thermo cycler (PTC-220, Bio-Rad, USA). The PCR conditions were as follows: $10 \mathrm{~min}$ at $94^{\circ} \mathrm{C} ; 35$ cycles of $1 \mathrm{~min}$ at $94^{\circ} \mathrm{C}, 1 \mathrm{~min}$ at $51^{\circ} \mathrm{C}$, and $1 \mathrm{~min}$ at $72^{\circ} \mathrm{C}$; and a final extension of 5 min at $72^{\circ} \mathrm{C}$. After confirmation of the PCR products on an agarose gel, DNA fragments of approximately 630 base pairs were extracted from the gel using the QIA quick PCR Purification Kit (Qiagen) and sequenced with a 3130XL Genetic Analyzer (Applied Bio systems, Foster City, CA, USA) using the Prism Big Dye Terminator Cycle Sequencing Kit.

\section{Data analysis}

DNA sequences were determined using DNA Sequencing Analysis Software (Applied Bio systems) and assembled using SeqMan software (DNASTAR Laser gene 8 package). Haplotype diversity and nucleotide diversity were calculated using Dna SP ver. 4.0 [26]. Population structures were investigated using analysis of molecular variance (AMOVA), and a possible geographical pattern in the distribution of genetic variability was analyzed through Fst estimates using Arlequin 3.0 [27]. Genetic distance matrices were used to construct an unweighted pair group method with arithmetic mean (UPGMA) genetic population relation tree with the POPULATION 1.2.30

\section{Results}

\section{Sequence analysis and variation among haplotypes}

PCR products of approximately 630 base pairs were obtained by amplification with the primers HCO2198 and LCO1490. The sequence, with the variable sites in bold, is shown in Figure 1. In the 46 polymorphic sites, transitions were observed at 40 sites, whereas transversions were detected at 6 sites. Based on the 46 variable sites, 23 haplotypes were identified among the 163 individuals (Table 1). Haplotype 1 (Hap_1; GenBank number HQ960853) and haplotype 7 (Hap_7; GenBank number HQ536319.1) were the most frequently observed sequences among C. auratus $(47.3 \%)$ and C. cuvieri $(62.8 \%)$, respectively. In contrast, the frequencies of these two haplotypes in opposite species were very low with the haplotype I and haplotype 7 frequency of $4.5 \%$ and $4.4 \%$ in C. cuvieri and C. auratus, respectively. The Hap_1 sequences of $C$. auratus and the Hap_7 sequences of $C$. cuvieri share $95 \%$ sequence identity. There was a clear difference in the haplotype frequencies for each species. Haplotypes 1, 3, 5, 9, and 16 were dominant in C. auratus, each with frequencies above $10 \%$. In contrast, in C. cuvieri, haplotypes 7, 11, and 13 had frequencies above $10 \%$. Therefore, there was no overlap of frequent haplotypes between the two species. However, haplotype 3 and 5 which were the main haplotype in C. auratus were present as minor haplotype in C. cuvieri from Yeongsan River. Similarly, haplotype 7, the other main haplotype in C. cuvieri, was observed as a minor haplotype in C. auratus from Yeongsan River. Therefore, further investigation on the gene flow between Carassius species in Yeongsan River is necessary.

\section{Population genetic structure and relationships}

The genetic relationships among $C$. cuvieri and $C$. auratus populations from the Nakdong, Yeongsan, and Geum rivers were analyzed. As shown in Figure 1, the two species formed clearly separated clusters, each comprising three populations from different locations. Among the $C$. auratus populations, the populations from the Yeongsan and Geum rivers clustered together. Similarly, the $C$. cuvieri populations from the Nakdong and Geum rivers formed a subcluster. Genetic differentiation among populations was assessed using FST pairwise comparisons. The three populations of $C$. cuvieri from the three rivers showed no genetic difference in the COI gene. In contrast, the three populations of $C$. auratus showed significant genetic differences in this gene. Furthermore, the genetic differentiation between the two species was also significant, with high FST values ranging from 0.3347 to 0.7588 . AMOVA results showed partitioning of the populations with significant variance $(\mathrm{P}<0.001)$. However, only $0.61 \%$ of the variation was attributed to the geographical separation of the populations; in contrast, $22.11 \%$ and $77.28 \%$ of the variations were

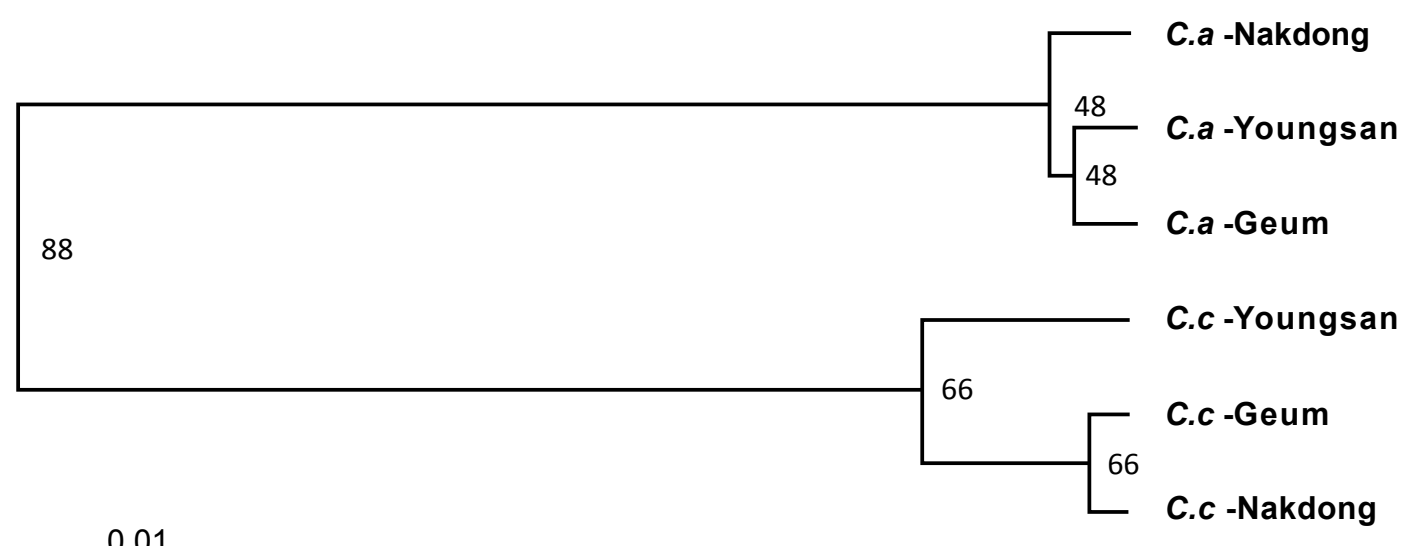

Figure 1: UPGMA tree of Carassiusauratus and C. cuvieri from six populations from Korea based on the mtDNA CO1 gene. 


\begin{tabular}{|c|c|c|c|c|c|c|}
\hline \multicolumn{4}{|c|}{ Species Carassiusauratus } & \multirow{2}{*}{\multicolumn{3}{|c|}{$\begin{array}{l}\text { Carassiuscutieri } \\
\text { C.c- Youngsan Cc- Nakdong } \\
\text { C.c- Geum }\end{array}$}} \\
\hline \multirow{3}{*}{$\begin{array}{l}\text { Population } \\
\text { Haplotwe }\end{array}$} & \multirow{2}{*}{\multicolumn{3}{|c|}{$\begin{array}{l}\text { C.a-Youngsan C.a-Nakdong } \\
\text { Ca- Geum } \\
\text { Carassiusauratus }\end{array}$}} & & & \\
\hline & & & & \multicolumn{3}{|c|}{ Carassiuscccuucutiericutieri } \\
\hline & Young= & Gem & Nakdong & Young= & Gem & Nakdong \\
\hline Hap_I & 0.444 & 0.7 & 0.276 & 0.071 & 0.063 & \\
\hline Hap_2 & 0.022 & & & & & \\
\hline Hap_3 & 0.267 & 0.15 & 0.276 & 0.036 & & \\
\hline Hap_4 & 0.022 & & & & & \\
\hline Hap_5 & 0.156 & & & 0.036 & & \\
\hline Hap_6 & 0.022 & 0.05 & 0.034 & & & \\
\hline Hap_7 & 0.044 & & & 0.5 & 0.688 & 0.696 \\
\hline Hap_8 & 0.022 & & & & & \\
\hline Hap9 & & 0.05 & 0.103 & & & \\
\hline Hap_10 & & 0.05 & & & & \\
\hline Hap_11 & & & & 0.286 & & 0.217 \\
\hline Hap_12 & & & & 0.071 & & \\
\hline Hap_13 & & & & & 0.125 & \\
\hline Hap_14 & & & & & 0.063 & \\
\hline H_15 & & & & & 0.063 & \\
\hline Hap_16 & & & 0.103 & & & \\
\hline Hap_17 & & & 0.034 & & & \\
\hline Hap_18 & & & 0.069 & & & \\
\hline Hap_19 & & & 0.034 & & & \\
\hline Hap_20 & & & 0.034 & & & \\
\hline Hap_21 & & & 0.034 & & & \\
\hline Hap_22 & & & & & & 0.043 \\
\hline Hap_23 & & & & & & 0.043 \\
\hline $\begin{array}{l}\text { No. of } \\
\text { individuals }\end{array}$ & 45 & 20 & 29 & 28 & 16 & 23 \\
\hline $\begin{array}{l}\text { Nucleotide } \\
\text { diversity,(\%) }\end{array}$ & 0.0154 & 0.0024 .002 & 0.0044 .002 & 0.0234 .014 & 0.0234 .014 & $0.020 \pm 0.011$ \\
\hline $\begin{array}{l}\text { No. of } \\
\text { Haplotype }\end{array}$ & 8 & 5 & 10 & 6 & 5 & 4 \\
\hline
\end{tabular}

Table 1: Summary of the distribution of haplotypes, nucleotide diversity, and number of polymorphic sites among populations of Carassiusauratus and $C$. cuvieri.

\begin{tabular}{|c|c|c|c|c|c|c|}
\hline \multirow{3}{*}{\begin{tabular}{|l|} 
Species \\
Population \\
Ca-Youngsan
\end{tabular}} & \multicolumn{2}{|c|}{ Carassi us OR rants } & & \multicolumn{3}{|c|}{ Carassiuscusieri } \\
\hline & \multicolumn{2}{|c|}{$\begin{array}{l}\text { C.a- Youngsan } \\
\text { C.a -Nakdong }\end{array}$} & \multirow{2}{*}{$\begin{array}{l}\text { C. a-Geuo2 } \\
0.0131\end{array}$} & \multicolumn{3}{|c|}{$\begin{array}{l}\text { C.c - Youngsan Cc- } \\
\text { NakdongC.c - Geum }\end{array}$} \\
\hline & 0 & 0.0177 & & 0.1945 & 0.4744 & 0.523 \\
\hline Ca-Nalcdong & $0.0961^{*}$ & 0 & 0.0135 & 0.2394 & 0.5522 & 0.6356 \\
\hline Ca-Geum & $0.0664^{*}$ & $0.2235^{\star}$ & 0 & 0.2364 & 0.5442 & 0.6231 \\
\hline Cc-Youngsan & $0.3347^{*}$ & 04710* & $0.4427^{*}$ & 0 & 0.047 & 0.0731 \\
\hline C.c-Nakdorg & $0.5305^{*}$ & $0.7246^{*}$ & $0.7074^{*}$ & 0.066 & 0 & 0.0106 \\
\hline C.c-Geum & $0.5946^{*}$ & 03588* & $0.7421^{*}$ & 0.0941 & -0.0243 & 0 \\
\hline
\end{tabular}

* Significant Fst value $(P<0.05)$

Table 2: Pairwise genetic distance (above diagonal) and Fst values (below diagonal) of Carassiusauratus and C. cuvieri.

attributed to variations between C. auratus and C. cuvieri (Table 2) and within the populations of each river, respectively.

\section{Discussion}

Among the diverse species and subspecies that belong to the genus Carassius, the endemic species C. auratus and the exotic species $C$. cuvieri are present in the freshwater ecosystems of Korea. In this study, the phylogenetic relationships of populations of the two species from three major rivers were analyzed.

Among the 46 polymorphic sites identified from 163 individuals, transitions (40 sites) were more frequent than transversions (6 sites), which is similar to the results of other Carassius mtDNA gene studies $[20,28]$. Alignment of the 46 polymorphic sites produced a total of 23 haplotypes. In the analysis of the first third of the mtDNA control region (CR; 323 base pairs), 35 haplotypes from 528 individuals were identified [3]. In contrast, only 14 haplotypes in the same region from 47 individuals were identified [29]. In the analysis of the COI gene of 160 individuals of the Carassius genera, 22 haplotypes were identified [28]. Therefore, the number of haplotypes may be related to the number of samples rather than the sequence length of the selected region.

Despite controversy over the classification of Carassius spp., there have been several reports of the genetic separation of $C$. cuvieri and C. auratus $[20,21,30,31]$. In the analysis of the mtDNA cytochrome $b$ (cyt b) and CR, it was demonstrated that C. cuvieri and C. alangsdorfii diverged later than the continental C. auratus forms (4.0-4.5 million years ago by molecular calibration) [30]. As expected, C. auratus and C. cuvieri in Korean freshwater systems also showed clear separation based on phylogenetic analysis of the COI gene (Figure 1).

Therefore, our results confirm previous findings [29,32], and support the current taxonomic treatment of $C$. cuvieri as a distinct species $[2,33,34]$. Although there have been many reports showing the genetic separation between C. auratus and C. cuvieri, there is no information on the genetic diversity among C. cuvieri populations in Japan, from which this species was introduced into Korea. In our analysis, the three populations of $C$. cuvieri from three rivers showed no genetic difference in the COI gene. Considering the geographical separation of the three river systems and the short time since the introduction of C. cuvieri, it seems likely that populations from the same origin in Japan were introduced into these rivers. Further study of $C$. cuvieri from Japan could better illustrate the genetic relationships among the C. cuvieri populations in Korea and Japan.

In contrast to the $C$. cuvieri populations, the three populations of $C$. auratus showed significant genetic distances. In phylogenetic analyses of a concatenated 4,669-base pair sequence containing the first third of the mtDNA CR, NADH dehydrogenase subunits 4 (ND4) and 5 (ND5), and cyt b gene sequences of the C. auratus complex, two old superlineages with high regional specificity, including one population on the Japanese main islands and the other consisting of populations distributed in various regions in and around the Eurasian continent were identified [3]. The molecular clock and fossil record of C. cuvieri suggested that these two superlineages separated between 4.01 and 0.39 Mya. Furthermore, seven clades representing the natural populations of each region were estimated by fossil records to have branched 0.2 Mya, and 1.0-1.9 Mya by molecular clock methods. Unfortunately, no sample from the Korean peninsula was included in their analysis. However, considering the origin of samples in their analysis, it is likely that $C$. auratus has branched and evolved over a long period of time as geographically separated populations in each river ecosystem.

Although C. auratus is currently one of the more abundant resources in Korean freshwaters, management is still necessary. For example, there have been several reports of recent dramatic decreases of Carassius fishes in Japan, which require special attention and management for recovery [35-37]. The introduction of related Carassius species, such as the case of the introduction of $C$. cuvieri into Korean freshwaters, can affect the ecology of endemic Carassius species. The possibility of hybridization among Carassius species in 
Citation: Kang JH, Noh ES, Lim JH, Han HK, Kim BS, et al. (2014) Genetic Differentiation of Carassius auratus and C. cuvieri by the Cytochrome C Oxidase I Gene Analysis. J Aquac Res Development 5: 231 doi:10.4172/2155-9546.1000231

Page 4 of 4

natural habitats [38] adds to the importance of resource management of these species. Our results indicate that each population of $C$. auratus in the different rivers of the Korean Peninsula needs to be managed as a separated genetic unit, whereas all C. cuvieri populations can be regarded as one genetic unit. However, further information with more samples will be necessary for the efficient management of these species.

\section{References}

1. Jang MH, Kim JG, Park SB, Jeong KS, Cho GI, et al. (2002) The current status of the distribution of introduced fish in large river systems of south korea. Internat. Rev. Hydrobiol 87: 319-328.

2. Hosoya K (2000) Cyprinidae, Fishes of japan with pictorial keys to the species. Tokai University Press, Tokyo.

3. Takada M, Tachihara K, Kon K, Yamamoto G, Iguchi K, et al. (2010) Biogeography and evolution of the Carassisus auratus - complex in East Asia. BMC Evolution Biology 10: 1-7.

4. Bănărescu P (1991) Zoogeography of fresh waters. Volume 2: distribution and dispersal of freshwater animals in North America and Eurasia.

5. Szczerbowski JA (2002) Cyprinidae 2, part III: Carassius to cyprinus. The freshwater fishes of Europe. Aula, Wiesbaden.

6. Szczerbowski JA (2002) Carassius auratus (Linnaeus, 1758). The freshwater fishes of Europe. Cyprinidae 2, Vol.5/III. AULA-.Verlag.

7. Kottelat M, Freyhof $\mathrm{J}$ (2007) Handbook of European freshwater fishes. Germany.

8. Chen H, Leibenguth F (1995) Studies on multilocus fingerprints, RAPD markers, and mitochondrial DNA of a gynogenetic fish (Carassius auratus gibelio). Biochemical Genetics 33: 297-306.

9. Ueda T, Ojima $Y$ (1978) Differential chromosomal characteristics in the Funa subspecies (Carassius). Proc. Japan Acad. 54: 283-288

10. Yu HX, Xu H, Guang HW, Li YQ, Zhang HM, Zong QX, Wang PL (1991) Preliminary study on the comprehensive genetics on crucian carp in Puan Country. Scientific Reports of the Shanghai Fisheries Research Institute 4: 4066.

11. Zhang H, Dong X, Ye Y, Wu Q (1998) Comparative studies of the mtDNA from three strains of triploid Carassius arratus and $\mathrm{C}$. auratus auratus. Acta Genetica Sinica 25: 330-336.

12. Chen MR, Yang XQ, Yu XM, Chen HX (1996) Kayotype studies on the bisexual natural cynogenetic crucian carp (Carassius auratus) of Pengze. Acta Hydrobio Sinica 20: 25.

13. Vasil'eva ED, Vasil'ev VP (2000) The origin and taxonomic status of the triploid form of the goldfish, Carassius auratus (Cyprinidae). Journal of Ichthyology 40: $553-563$

14. Abramenko MI, Kravchenko OV, Velikoivanenko AE (1997) Population genetic structure of the goldfish Carassius auratus gibelio diploid-triploid complex from the Don River Basin. Journal of Ichthyology 37: 56-65.

15. Xiao J, Zou T, Chen Y, Chen L, Liu S, et al. (2011) Coexistence of diploid triploid and tetraploid crucian carp (Carassius auratus) in natural waters. BMC Genetics 12: 20.

16. Hänfling B, Bolton P, Harlea M, Carvalho GR (2005) A molecular approach to detect hybridization between crucian carp (Carassius carassius) and nonindigenous carp species (Carassius spp. and Cyprinus carpio). Freshwater Biology 50: 403-417.

17. Suzuki T, Nagano H, Kobayashi T, Ueno K (2005) Seasonal changes in the number of larvae and juveniles of crucian carps in the reed zone of Lake Biwa based on (sub) species identification using RAPD markers. Nippon Suisan Gakkaishi 71: 10-15.

18. Jorge HU, Manuel V, Susana M, Ania PQ, Paulino M, et al. (2012) Development and validation of a molecular tool for assessing triploidy in turbot (Scophthalmus maximus). Aquaculture 380-383: 179-184.

19. Mishina T, Takada M, Takeshima H, Nakano M, Ryoichi T, et al. (2014) Molecular identification of species and ploidy of Carassius fishes in Lake Biwa, using mtDNA and microsatellite multiplex PCRs. Ichthyol Res 61: 169-175.

20. Yamamoto G, Takada M, Iguchi K, Nishida M (2010) Genetic constitution and phylogenetic relationships of Japanese crucian carps (Carassius). Ichthyological Research 57: 215-222.

21. Kalous L, Bohlen J, Rylková K, Petrtýl M (2012) Hidden diversity within the Prussian carp and designation of a neotype for Carassius gibelio (Teleostei: Cyprinidae). Ichthyological Exploration of Freshwaters 23: 11-18.

22. Cheng L, Chang YM, Lu CY, Cao DC, Sun XW (2012) DNA barcoding and species and subspecies classification within genus Carassius sp. Zoological Research 33: 463-472.

23. Luo J, Yhang YP, Zhu CL, Xiao WH, Huang SY (1999) Genetic diversity in crucian carp (Carassius auratus). Biochemical Genetics 37: 267-279.

24. Galtier N, Nabholz B, Glemin S, Hurst GAD (2009) Mitochondrial DNA as a marker of molecular diversity: a reappraisal. Molecular Ecology 18: 4541-4550.

25. Folmer O, Black M, Hoeh W, Lutz R, et al (1994) DNA primers for amplification of mitochondrial cytochrome $\mathrm{c}$ oxidase subunit I from diverse metazoan invertebrates. Mol Mar Biol Biotechnol 3: 294-299.

26. Rozas J (2003) DnaSP: DNA polymorphism analyses by the coalescent and other methods. Bioinformatics 19: 2496-2497.

27. Excoffier L, Laval G, Schneider S (2005) ARLEQUIN ver. 3.0. An integrated software package for population genetics data analysis. Evol Bioinform Online 1: 47-50.

28. Ionescu ML, Chiorghita GI (2013) The study of genetic diversity within Carassius genera, based on sequencing some mitochondrial markers. Bioresearch 1: 2939.

29. Iguchi K, Yamamoto G, Matsubara N, Nishida M (2003) Morphological and genetic analysis of fish a Carassius complex (Cyprinidae) in Lake Kasumigaura with reference to the taxonomic status of two all-female triploid morphs. Biological Journal of the Linnean Society 79: 351-357.

30. Podlesnykh AV, Apalikova OV, Brykov VA (2012) Phylogenetic relationships of silver crucian carp in Carassius auratus complex based on mtDNA analysis. Russian Journal of Genetics 48: 1207-1217.

31. Rylkova K, Kalous L, Bohlen J, Lamatsch DK, Petrtyl M (2013) Phylogeny and biogeographic history of the cyprinid fish genus Carassius (Teleostei Cyprinidae) with focus on natural and anthropogenic arrivals in Europe. Aquaculture 380-383: 13-20

32. Murakami M, Matsuba $C$, Fujitani $H$ (2001) The meternal origins of the triploid ginbuna (Carassius auratus langsdorfi): phylogenetic relationships within the $\mathrm{C}$ auratus taxa by partial mitochondrial D-loop sequencing. Genes and Genetic Systems 76: 25-32.

33. Mitadi D, Kawanabe H, Mizuno N (1976) Coloured illustrations of the freshwater fishes of Japan. Hoikusya, Osaka.

34. Maita M, Taniguchi N, Koedprang W, Nakajima M (2001) Genetic variation on hematology and plasma chemistry traits of silver crucian carp, Carassius langsdorfii collected from natural habitat. Suisanzoshoku 49: 97-102.

35. Suzuki T, Kobayashi T, Ueno K (2008) Genetic identification of larvae and juveniles reveals the difference in the spawning site among Cyprininae fish species/subspecies in Lake Biwa. Environ Biol Fish 82: 353-354.

36. Fujiwara K (2011) Early life ecology of nigorobuna Carassius auratus grandoculis in reed zone of Lake Biwa and physiological adaptation to the environment. Nippon Suisan Gakkaishi 77: 387-401.

37. Fujioka $Y$ (2013) Present status and conservation of the endangered endemic Lake Biwa cyprinids, Honmoroko (Gnathopogon caerulescens), Nigorobuna (Carassius auratus grandoculis), and Gengorobuna (Carassius cuvieri). Jpn J Ichthyol 60: 57-63.

38. Papousek I, Vetesnik L, Halacka K, Luskova V, Humpl M, et al. (2008) Identification of natural hybrids of gibel carp Carassius auratus gibelio (Bloch) and crucian carp Carassius carassius (L.) from lower Dyje River floodplain (Czech Republic). Journal of Fish Biology 72: 1230-1235. 